\title{
PENINGKATAN KEMAMPUAN APRESIASI SASTRA SISWA SMP MELALUI MODEL INVESTIGASI KELOMPOK
}

\author{
Krismelinda ${ }^{1}$, Widya Andayani ${ }^{2}$, Rita Hartati, Tiarnita M.S. Siregar ${ }^{3}$, \\ Imelda Malawaty Simorangkir ${ }^{4}$
}

Universitas Negeri Medan $^{1,2,3}$, Universitas Indraprasta PGRI Jakarta ${ }^{4}$

\section{KEYWORDS}

\section{ABSTRACT}

Metode investigasi
kelompok,
Apresiasi sastra
appreciate literature while at the same time increasing the interest and ability of the students of
SMP Negeri 14 Binjai towards literary works. The research conducted was Classroom Action
Research (CAR) with the research subject of 25 grade IX students of SMP Negeri 14 Binjai in the
2020/2021 academic year. The object of this research is the ability of students to rewrite the
contents of the story (rewrite), retell the story (retell), and conclude the moral message as well as
relate it to student life (reflection). The learning process to appreciate literature is carried out in
two cycles through four stages, namely: the action planning stage, the action implementation stage,
the observation stage, and the analysis and reflection stage. Based on the results of the study, it can
be concluded that the students' ability to appreciate literature increases, this is indicated by the
increase in the results of the three tests (rewrite, retell, reflection) of students at the end of each
cycle. The average value of students' appreciation of literature has increased in each cycle, namely:
1) in the initial survey as many as 7 students $(28 \%$ ) of the total students who achieved a complete
score, with an overall average score of $62.76 ; 2)$ in the first cycle, 15 students $(60 \%)$ achieved a
complete score, with an average overall score of $66.88 ; 3)$ in the second cycle there was a drastic
increase in student mastery, namely a total of 25 students (100\%) achieving a complete score with
an average value of 78.8.

\section{KATA} KUNCI

\section{ABSTRAK}

\section{Metode investigasi \\ kelompok,}

Apresiasi sastra

\begin{abstract}
Tujuan dari penelitian ini adalah untuk menerapkan model pembelajaran yang efektif dalam meningkatkakan kemampuan mengapresiasi sastra sekaligus meningkatkan minat dan kemampuan siswa SMP Negeri 14 Binjai terhadap karya sastra. Penelitian yang dilakukan adalah Penelitian Tindakan Kelas (PTK) dengan subjek penelitian 25 siswa kelas IX SMP Negeri 14 Binjai tahun ajaran 2020/2021. Objek penelitian ini adalah kemampuan siswa dalam menuliskan kembali isi cerita (rewrite), menceritakan kembali cerita (retell), dan menyimpulkan pesan moral sekaligus mengaitkannya dengan kehidupan siswa (reflection). Proses pembelajaran mengapresiasi sastra ini dilakukan dalam dua siklus melalui empat tahap, yaitu: tahap perencanaan tindakan, tahap pelaksanaan tindakan, tahap observasi, dan tahap analisis dan refleksi. Berdasarkan hasil penelitian dapat disimpulkan bahwa kemampuan siswa dalam mengapresiasi sastra meningkat, hal ini ditandai dengan meningkatnya hasil ke tiga tes (rewrite, retell, reflection) siswa diakhir setiap siklus. Nilai rata-rata mengapresiasi sastra siswa mengalami peningkatan di setiap siklu, yaitu: 1) pada survei awal sebanyak 7 siswa $(28 \%)$ dari keseluruhan siswa yang mencapai nilai tuntas, dengan rata-rata nilai keseluruhan yaitu 62,76 ; 2) pada siklus I sebanyak 15 siswa (60\%) yang mencapai nilai tuntas, dengan rata-rata nilai keseluruhan 66,88 ; 3) pada siklus II adanya peningkatan yang drastis pada ketuntasan siswa, yaitu total 25 siswa $(100 \%)$ mencapai nilai tuntas dengan nilai ratarata 78,8 .
\end{abstract}

\section{APA $7^{\text {th }}$ Citation:}

Krismelinda, et al. 2022. Peningkatan Kemampuan Apresiasi Sastra Siswa SMP Melalui Model Investigasi Kelompok. Wacana:Jurnal Penelitian Bahasa, Sastra dan Pengajaran, Vol.20 (1), 12-16 DOI: https://doi.org/10.33369/jwacana

\section{PENDAHULUAN}

Berbicara tentang belajar sastra, hal-hal yang dapat dilakukan tak hanya sebatas menciptakan karya dan sekedar menikmati saja, tetapi ada kegiatan yang lebih menitikberatkan pada penghayatan dan penilaian suatu karya, yaitu kegiatan mengapresiasi. Apresiasi sastra merupakan kegiatan yang berkaitan dengan karya sastra, seperti menonton, 
mendengarkan dan membaca karya sastra, serta menulis karya sastra dengan penuh penghayatan (Andayani, 2009).

Kemahiran dalam mengapresiasi sastra dapat dibiasakan melalui proses kegiatan belajar mengajar di bangku sekolah, khususnya pada mata pelajaran wajib yaitu Bahasa Indonesia dan Bahasa Inggris. Hal mendasar dalam mengapresiasi sastra yaitu dengan membaca karyakarya sastra terdahulu. Tetapi sayangnya, minat membaca siswa Indonesia masih sangat rendah. Berdasarkan penelitian yang dilakukan pada siswa SMP Katolik Santo Paulus Palu, dari 16 siswa yang ada, hanya 10 siswa yang terkadang mengisi waktu luangnya dengan kegiatan membaca, dan hampir setiap siswa merasa terkadang tidak ada yang kurang jika tidak membaca dalam sehari (Nora, 2020).

Oleh karena itu, guru diharapkan mampu untuk menerapkan model pembelajaran yang dapat meningkatkan minat siswa terhadap karya-karya sastra. Salah satu model pembelajaran yang dapat diterapkan adalah Metode Investigasi Kelompok (MIK). Investigasi kelompok merupakan salah satu strategi pembelajaran kooperatif (Slavin, 2005), di mana siswa bekerja secara kolaboratif dalam kelompok-kelompok kecil yang terdiri dari dua sampai enam orang dengan struktur kelompok yang heterogen.

Penelitian ini berfokus pada penerapan model pembelajaran yang efektif dalam meningkatkakan kemampuan mengapresiasi sastra sekaligus meningkatkan minat dan kemampuan siswa SMP Negeri 14 Binjai terhadap karya sastra. Melalui metode investigasi kelompok, siswa diharapkan dapat mengapresiasi suatu karya sastra dengan baik. Siswa diberikan sebuah cerita pendek dan melakukan kegiatan mengapresiasi, yaitu: menuliskan kembali isi cerita (rewrite), menceritakan ulang cerita (retell), dan mengambil refleksi dari cerita tersebut (reflection). Dengan mengadopsi metode inkuiri kelompok, siswa dapat berpartisipasi aktif dalam kegiatan pembelajaran baik secara individu maupun kelompok, dan pembelajaran pada mata pelajaran bahasa menjadi lebih kualitatif.

\section{METODE}

Penelitian ini merupakan Penelitian Tindakan Kelas. Kunandar (2011) berpendapat ahwa penelitian tindakan kelas adalah penelitian tindakan dalam pendidikan yang dilakukan oleh guru dengan orang lain (peneliti) yang secara kolaboratif merancang, melaksanakan dan merefleksikan tindakan proses pembelajaran di kelasnya dengan tindakan (perlakuan) tertentu untuk sejumlah siklus. Pembelajaran ditingkatkan dengan menggunakan model Group Investigation (Investigasi Kelompok) untuk siswa yang menjadi objek penelitian.

Penerapan model pembelajaran ini dalam pembelajaran apresiasi memungkinkan siswa berpartisipasi secara aktif dan bermakna dalam kegiatan pembelajaran baik secara individu maupun kelompok sehingga pembelajaran apresiasi menjadi lebih menyenangkan dan berkualitas. Rencana penelitian tindakan kelas dilaksanakan dalam dua siklus, yang terdiri dari empat tahap setiap siklusnya, yaitu (1) perencanaan, (2) pelaksanaan, (3) observasi, dan (4) analisis dan refleksi. (merefleksikan).

Penelian yang dilakukan secara daring ini (dalam jaringan) menggunakan instrumen penelitian berupa tes bentuk penugasan secara tertulis dan secara oral untuk mengetahui sejauh mana pemahaman siswa terhadap materi yang diberikan dengan menggunakan model investigasi kelompok pada siklus 1 dan siklus 2 .

Data pada penelitian ini dianalisis menggunakan Teknik statistik deskriptif, frekuensi hitung, dan persentase yang disajikan dengan tabel. Nilai dan persentasi yang diberikan berdasarkan kritis terhadap kemampuan siswa dalam menulis kembali, menceritakan dan mengungkapkan pendapat tentang pesan moral yang terkandung pada karya sastra berbahasa Inggris yang pertama kali baca. Kategori dalam data disesuaikan berdasarkan persentase yang ada. Rumus yang akan digunakan dalam pengolahan data adalah sebagai berikut: 
Tabel 2. Indikator ketercapaian.

\begin{tabular}{|c|c|c|}
\hline No & Nilai & Keterangan \\
\hline 1 & $>70$ & Buruk \\
\hline 2 & 70 & Cukup \\
\hline 3 & $71-79$ & Sedang \\
\hline 4 & $80-89$ & Baik \\
\hline 5 & $90-100$ & Sangat Baik \\
\hline
\end{tabular}

\begin{tabular}{|c|c|c|}
\hline No & Nilai & Keterangan \\
\hline 1 & $<70$ & Tidak Tuntas \\
\hline 2 & 270 & Tuntas \\
\hline
\end{tabular}

\section{HASIL DAN PEMBAHASAN}

Berdasarkan hasil observasi pada pada 25 siswa di pra siklus (survei awal) dan kedua siklus (siklus I and II), terlihat bahwa pelaksanaan Model Investigasi Kelompok (MIK) telah mencapai target yang diharapkan, karena terjadinya peningkatan nilai disetiap siklus yang dilakukan.

Tabel 3. Daftar rata-rata nilai apresiasi sastra.

\begin{tabular}{|c|l|c|c|c|c|}
\hline \multirow{2}{*}{ No } & \multicolumn{1}{|c|}{ Kegiatan Siswa } & \multicolumn{3}{|c|}{ Rata-rata Nilai } & \multirow{2}{*}{ Keterangan } \\
\cline { 3 - 5 } & \multicolumn{1}{|c|}{ Survei awal } & Siklus I & Siklus II & Meningkat \\
\hline 1 & $\begin{array}{l}\text { Menuliskan kembali } \\
\text { cerita (rewrite) }\end{array}$ & 21,6 & 22,76 & 24,44 & Meningkat \\
\hline 2 & $\begin{array}{l}\text { Menceritakan kembali } \\
\text { (retell) }\end{array}$ & 17,84 & 20,24 & 26,68 & Meningkat \\
\hline 3 & Refleksi (reflection) & 23,32 & 23,88 & 27,68 & Meningkat \\
\hline & TOTAL RATA-RATA & $\mathbf{6 2 , 7 6}$ & $\mathbf{6 6 , 8 8}$ & $\mathbf{7 8 , 8}$ & \\
\hline
\end{tabular}

Tabel 4. Hasil tindakan berdasarkan indikator ketercapaian ptk.

\begin{tabular}{|l|c|c|c|}
\hline \multirow{2}{*}{ Kegiatan Siswa } & \multicolumn{3}{|c|}{ Persentase } \\
\cline { 2 - 4 } & Survei awal & Siklus I & Siklus II \\
\hline Mengapresiasi sastra & $28 \%$ & $60 \%$ & $100 \%$ \\
\hline
\end{tabular}

Berdasarkan tabel di atas, terdapat peningkatan atas indikator yang ditetapkan peneliti sebagai akibat dari pengambilan tindakan pada setiap siklusnya. Pada survei awal hanya 7 orang (28\%) dari keseluruhan siswa yang mencapai nilai tuntas, dengan rata-rata nilai keseluruhan yaitu 62,76. Pada siklus I mulai ada peningkatan yaitu 15 siswa (60\%) yang mendapatkan nilai tuntas, dengan rata-rata nilai keseluruhan 66,88. Adanya peningkatan yang drastis di siklus II pada ketuntasan siswa, yaitu total 25 siswa (100\%) mencapai nilai tuntas dengan nilai rata-rata 78,8 .

Berdasarkan tindakan dari survei awal, siklus I dan siklus II, peneliti dikatakan berhasil meningkatkan kualitas siswa pada pembelajaran apresiasi sastra dengan menerapkan metode investigasi kelompok. Penelitian ini juga akan membantu meningkatkan keterampilan manajemen kelas peneliti. Metode ini dapat digunakan untuk memotivasi siswa agar lebih aktif dalam kegiatan mengapresiasi karya sastra.

Indikator keberhasilan penerapan metode investigasi kelompok dalam upaya peningkatan kualitas pembelajaran apresiasi sastra baik secara proses dan hasil adalah sebagai berikut:

\section{Kualitas Proses Pembelajaran Apresiasi Sastra}


Tindakan-tindakan yang dilaksanakan dalam tiap siklus dapat meningkatan kualitas proses belajar apresiasi sastra siswa kelas IX SMP Negeri 14 Binjai. Hal ini bisa dicermati dalam indikator-indikator berikut:

\section{a. Kerja Sama dengan Anggota Kelompok Selama Proses Pembelajaran}

Kerjasama merupakan kegiatan dimana siswa dapat bekerja bersama-sama dengan anggota kelompok lain dalam memecahkan suatu masalah. Setiap kelompoknya terdiri dari 5 siswa. Siswa yang dapat mengapresiasi karya sastra dengan nilai yang tinggi diharapkan dapat membantu siswa lain yang mengalami kesulitan. Indikator kerjasama ini meliputi: Membantu menjelaskan kepada teman ketika materi yang disampaikan peneliti kurang jelas dan menciptakan interaksi yang berkesinambungan untuk saling mendukung.

\section{b. Keaktifan Siswa Selama Pembelajaran Apresiasi Sastra}

Siswa dinilai keaktifannya didalam proses pembelajaran apresiasi sastra. Peneliti menentukan indikator penilaian keakfitan siswa, yaitu apakah siswa mengajukan pertanyaan, dan apakah siswa memperhatikan pertanyaan yang diajukan temannya.

\section{c. Minat Siswa Terhadap Pembelajaran Apresiasi Satra}

Semangat dan kemauan siswa dalam mengikuti proses kegiatan belajar apresiasi sastra merupakan fokus penilaian pada indikator minat siswa ini. Sub indikator peneliti pada peniliaian ini adalah siswa sigap membentuk kelompok-kelompoknya, siswa menyelesaikan tugas yang diberikan dengan tepat waktu, siswa mampu fokus dalam jalannya diskusi kelompok tanpa melakukan aktivitasnya sendiri, seperti (bermain handphone, keluar dari breakout room, mematikan suara/mute, dan mematikan kamera).

Adapun rincian peningkatan kerja sama, keaktifan dan minat siswa dalam pembelajaran apresiasi sastra ini dapat dilihat dari meningkatnya nilai yang mereka dapatkan pada pra siklus sampai siklus II, yang tertera sebagai berikut: pada survei awal (pra siklus) tercatat 18 siswa mendapat nilai buruk $(<70), 1$ siswa mendapat nilai cukup $(70)$, 3 siswa mendapat nilai sedang (71-79), 3 siswa mendapat nilai baik (80-89), 0 siswa mendapat nilai sangat baik (90-100). Pada siklus I tercatat 10 siswa mendapat nilai buruk $(<70), 6$ siswa mendapat nilai cukup (70), 6 siswa mendapat nilai sedang (71-79), 3 siswa mendapat nilai baik (80-89), 0 siswa mendapat nilai sangat baik (90-100). Pada siklus II tercatat 0 siswa mendapat nilai buruk $(<70)$, 3 siswa mendapat nilai cukup (70), 10 siswa mendapat nilai sedang (71-79), 9 siswa mendapat nilai baik (80-89), 3 siswa mendapat nilai sangat baik (90)$100)$.

\section{Kualitas Hasil Pembelajaran Apresiasi Sastra}

Penerapan metode investigasi kelompok juga dapat meningkatkan kualitas hasil literasi siswa kelas IX SMP Negeri 1 Binjai. Hal ini terlihat pada indikator berikut ini:

\section{a. Hasil Kegiatan Menulis Ulang Cerita Pendek}

Siswa dapat menulis ulang cerita pendek yang didengar dalam bahasa mereka sendiri dengan bekerja dalam kelompok. Hal ini semakin menambah bobot tulisan mereka karena mereka menggunakan kata yang berbeda tetapi memiliki arti yang sama sehingga isi cerita tidak berubah. Hal ini menjadi dasar bagi peneliti untuk menentukan berapa nilai yang akan didapat dan menetapkan bahwa metode investigasi kelompok dapat diterapkan dalam pembelajaran lainnya untuk meningkatkan nilai dan kualitas tulisan siswa.

Pada survei awal dan setiap siklus indikator ini mengalami peningkatan yang signifikan. Hal ini terlihat dari nilai siswa yang mengalami peningkatan setiap siklusnya. Pada periode pra siklus, nilai terendah siswa pada indikator ini adalah 9; pada siklus I nilai terendah siswa adalah 16; dan pada siklus II nilai siswa terendah adalah 21.

\section{b. Hasil Kegiatan Menceritakan Kembali Cerita Pendek}

Siswa mampu menceritakan kembali cerita pendek yang diperdengarkan dengan baik, lancar, efektif, dan sesuai dengan cerita aslinya. Hal ini melatih mereka untuk lebih berani dalam berbicara didepan umum serta meningkatkan kepercayaan diri mereka akan pengetahuan yang sudah mereka miliki dan membagikannya didepan umum. 
Pada survei awal dan setiap siklus, indikator ini mengalami peningkatan. Hal ini dalap dilihat dari nilai siswa yang mengalami peningkatan dari siklus ke siklus. Pada pra siklus (survei awal), skor terendah siswa dalam indikator ini adalah 10; pada siklus I skor terendah siswa adalah 11; dan pada siklus II skor terendah siswa adalah 21.

\section{c. Hasil Kegiatan Menyampaikan Pesan Moral dari Cerita Pendek}

Siswa mampu mengemukakan pendapat dan pandangan mereka tentang pesan dan pelajaran yang didapat setelah mengapresiasi cerita pendek. Hal ini melatih mereka untuk melihat sesuatu dari sudut pandang yang berbeda dan memiliki pendapat sendiri adalah suatu hal yang baik untuk dilakukan.

Pada survei awal dan setiap siklus, indikator ini mengalami peningkatan. Hal ini dalap dilihat dari nilai siswa yang mengalami peningkatan dari siklus ke siklus. Pada pra siklus (survei awal), skor terendah siswa dalam indikator ini adalah 15; pada siklus I skor terendah siswa adalah 17; dan pada siklus II skor terendah siswa adalah 23.

\section{KESIMPULAN}

1. Ada peningkatan kualitas proses pembelajaran pengapresiasi karya sastra dalam bentuk cerita pendek pada siswa kelas IX SMP Negeri 14 Binjai berikut ini:

a. Adanya peningkatan kualitas menulis ulang cerita pendek. Pada indikator ini terjadi peningkatan pada survei awal dan setiap siklus. Pada survei awal menunjukan sebesar 64\%, pada siklus I menunjukkan sebesar 72\%, dan pada siklus II menunjukan sebesar $100 \%$.

b. Adanya peningkatan kualitas berbicara dalam menceritakan ulang cerita pendek yang diapresiasi. Walaupun pada survei awal dan siklus I tidak menunjukan peningkatan yang signifikan, yaitu dari $8 \%$ ke $24 \%$, namun pada siklus II peningkatan naik menjadi $76 \%$.

c. Adanya penurunan dan peningkatan kualitas dalam menyampaikan pandangan siswa tentang pesan moral yang diperolah dari cerita pendek. Dari survei awal sebesar 52\%, pada siklus I menurun menjadi 48\%, penurunan ini disebabkan oleh kesulitan mereka dalam menggabungkan isi pikiran mereka pada diskusi pertama. Lalu pada pada siklus II meningkat menjadi $92 \%$.

2. Hasil belajar sastra berbentuk cerpen siswa kelas IX SMP Negeri 14 Binjai mengalami peningkatan. Pada survey awal nilai terendah 43 dan nilai tertinggi 85 dan terdapat 7 siswa atau $28 \%$ siswa yang mendapat nilai penuh. Pada jenjang sarjana nilai terendah adalah 50 dan nilai tertinggi adalah 89 dan terdapat 15 siswa atau $60 \%$ siswa dengan nilai penuh. Dan pada siklus II nilai terendah 70 dan nilai tertinggi 93 serta terdapat 25 siswa atau $100 \%$ siswa mendapatkan nilai penuh.

\section{DAFTAR PUSTAKA}

Andayani. 2009. Bahasa Indonesia. Surakarta : Panitia Sertifikasi Guru (PSG) Rayon 13 Surakarta

Nora, K. (2020). Minat Membaca Siswa Kelas Viii C Smp Katolik Santo Paulus Palu. Jurnal Bahasa dan Sastra, 90-97.

Slavin, R.E. 2005. Cooperative Learning: Teori, Riset, dan Praktek. Bandung: Nusa Media. 